\title{
Attitudes to and effects of fasting on Yom Kippur in cancer patients receiving chemotherapy: To fast or not to fast on Yom Kippur
}

\author{
Tal Grenader, Linda Shavit \\ Department of Oncology, Shaare Zedek Medical Center, Jerusalem, Israel
}

Correspondence: Tal Grenader. Address: Department of Oncology, Sha'are Zedek Medical Center, P.O. Box 3235,91031 Jerusalem, Israel. E-mail: talgrenader65@hotmail.com.

Received: January 29, 2013

DOI : $10.5430 /$ jnep.v4n1p12
Accepted: March 21, $2013 \quad$ Online Published: May 28, 2013

URL: http://dx.doi.org/10.5430/jnep.v4n1p12

\section{Abstract}

Background: Almost four-fifth of the Jewish people in Israel fast on Yom Kippur. The Jewish law exempts patients from fasting if the fast endangers the patient's health. There no previous study has focused on Yom Kippur fasting in the cancer patients treated with chemotherapy. The aim of the present study, therefore, was to assess attitudes towards fasting on Yom Kippur in these patients, and tolerance of the 25-hour fast in those who observed it.

Methods: The sample comprised 31cancer patients receiving chemotherapy in the Day Care Unit of Shaare Zedek Medical Center, all of whom were individually interviewed regarding fasting on Yom Kippur. Patients were asked whether they were fasting on Yom Kippur, whether sought an oncologist's or Rabbis advice was sought before undertaking fasting, and what that advice was. The following data were collected for all participants: age, gender, the stage of the cancer (metastatic vs nonmetastatic), religious status and social status. The data were transcribed into an electronic database within Microsoft Excel®.

On the day of interview, all participants were examined by oncology day care nursing staff. The examination included vital signs, symptom and well being questionnaire and routine blood test examination.

Results: Chemotherapy-treated patients tended to ask their doctor or Rabbi whether they should fast on Yom Kippur. In the majority of cases they were advised not to fast or a form of partial fasting was recommended. Regardless of advice by doctors and Rabbis to the contrary, 6 patients chose to observe the fast strictly, despite chemotherapy; 12 to drink Shiurim (Minimum Quantities) and only 11 decided not to fast.

In general, the 25-hour fast was well tolerated. All 6 patients who observed it strictly completed it successfully. Five of these reported normal activity during the fast and one felt weaker than normal. Ten of the 12 drinking Shiurim completed the 25 hours of the fast; 9 of these reported normal activity during the fast and 3 felt weaker than normal.

Conclusions: Most patients who traditionally fasted in Yom Kippur asked their doctor and/or Rabbi's advice regarding fasting. Despite recommendations to the contrary, most patients continued to fast, and in general, tolerated it well.

\section{Key words}

Yom Kippur, Day of Atonement, Fasting, Cancer, Chemotherapy 


\section{I ntroduction}

Yom Kippur, or the Day of Atonement, is arguably the most important day in the calendar for the majority of Jews. It is the day on which Jews confess misdeeds of the past year, truly repent, and pray earnestly and sincerely for forgiveness from the Almighty. The Torah states that on Yom Kippur "you shall afflict your souls", which is understood to mean that one should fast throughout the day - in all, a period of 25 hours. Because of the awe and solemnity of the occasion, fasting and attendance in the synagogue are observed by many Jews who might otherwise lead essentially secular lives. It is estimated that around $80 \%$ of all adult Jews in Israel fast on Yom Kippur.

The humanity of the Jewish law is such that individuals whose health would be endangered by abstaining from food and drink on Yom Kippur are not compelled to fast. Since observing the fast on this day assumes such an importance for the majority of Jews, however, Jewish law would generally advise the elderly and the sick to follow the advice of their physicians who are in the best position to decide whether they can fast or not ${ }^{[1,2]}$. When oncology patients consult their clinician on this subject, the advice given must take full account of the individual patient's religious sensibilities as well as the nature and status of his or her medical condition.

The prohibition against eating or drinking on Yom Kippur extends even to tiny amounts. However, the penalty for violating this prohibition applies only if a certain quantity (shiur) of food or drink is consumed. Therefore, one for whom fasting is dangerous may sometimes be instructed to eat or drink less than a shiur at one time.

The shiur for drinking is half of one mouthful (measured before the fast by filling the mouth and cheeks with liquid, emptying it into a measuring cup, and halving that). If eating is necessary, a patient may eat up to 30cc at a time. Ideally, these quantities should be consumed at intervals of at least nine minutes; however, opinions vary and some authorities permit intervals as short as four minutes ${ }^{[3]}$.

The issue of fasting on Yom Kippur has great importance for cancer patients receiving chemotherapy, often putting them in a stressful and anxious condition. This is relevant with religious patients as with irreligious as one.

To the best of our knowledge no previous study has focused on Yom Kippur fasting in cancer patients treated with chemotherapy. The present study is designed to fill this gap and the aim of the present study was to investigate if cancer patients who receive chemotherapy fast in Yom Kippur and how they tolerate the 25-hour fast.

\section{Methods}

This interview study is a research project on persons with cancer treated by chemotherapy. The research project has been approved by the Hospital Ethical Review Board, Shaare Zedek Medical Center, Jerusalem, Israel. All patients consented to participate in the study.

The participants were guaranteed confidentiality and informed that participation was voluntary and that they could terminate their interview at any time without giving a reason. Patients were asked whether they were fasting on Yom Kippur, whether sought an oncologist's or Rabbis advice was sought before undertaking fasting, and what that advice was. The following data were collected for all participants: age, gender, the stage of the cancer (metastatic vs nonmetastatic), religious status and social status. On the day of interview, all participants were examined by oncology day care nursing staff. The examination included vital signs as blood pressure and pulse, symptom and well being questionnaire and routine blood test examination including complete blood count and biochemistry.

All of the interviews were performed during the first post Yom Kippur chemotherapy treatment.

The data were transcribed into an electronic database within Microsoft Excel®. 


\section{Participants}

The inclusion criteria to participate in the study were: Jewish adults ( $>18$ years), diagnosed with solid tumors currently treated with chemotherapy. Patients were excluded if they have poor general condition or significant cognitive impairment. Contact was made with the oncology nurses at Oncology Day Care Unit of Shaare Zedek Medical Center in order to obtain information regarding Yom Kippur fasting in oncology patients who fulfilled the inclusion criteria.

The study included 31 people, 11 men and 20 women, in the age range 34-89 years (mean 62.3 years) 8 patients received adjuvant chemotherapy and 23 received chemotherapy for metastatic disease. Characteristics of the participants are presented in Table 1.

Table 1. Patients characteristic

\begin{tabular}{lll}
\hline Character & $\mathbf{N}$ & $\mathbf{\%}$ \\
\hline Gender & & \\
Male & 11 & 35 \\
Femalle & 20 & 65 \\
Age: mean (range) & 62.3 years ( 34-89 years) & \\
Religious status & & \\
Secular & 3 & 9.7 \\
Conservative- Religious & 8 & 25.8 \\
Religious-Zionist & 14 & 45.2 \\
Religious-Haredi & 6 & 19.3 \\
Civil status & & \\
Unmarried & 2 & 6.5 \\
Married & 21 & 67.7 \\
Divorced & 6 & 19.3 \\
Widow/widower & 2 & 6.5 \\
\hline
\end{tabular}

\section{Results}

Before being treated with chemotherapy, 28 of 31 participants had traditionally fasted on Yom Kippur. Of these, 23 asked their oncologist permission to fast in this year and 20 asked their rabbi, 4 in previous years and 2 in current and previous years. In 1 case the doctor gave consent to fast, in 9 cases partially fasting or fast by Shiurim was recommended and in 13 cases fasting was prohibited.

In no case did the Rabbis recommend fasting, in 5 cases partially fasting or fast by Shiurim was recommended, in 6 cases the question was referred to their oncologist and in 9 cases fasting was prohibited.

Despite their doctors and Rabbis' recommendations, 6 continued to fast on Yom Kippur despite chemotherapy, 12 to eat by Shiurim (Minimum Quantities) and only 11 did not fast.

Generally, the 25-hour Yom Kippur fast was well tolerated. The general condition and well being did not change from the baseline. Patients did not complain on general weakness, dizziness, pain or gastrointestinal symptoms that increased during the fast. All 6 fasting patients succeeded in completing the full 25 hours. 10 of 12 drinking by Shiurim completed 25 hours of fast. 5 of 6 fasting patients reported normal activity during the fast and 1 was weaker than usual. 9 of 12 patients drinking by Shiurim reported normal activity during the fast and 3 were weaker than usual. 
Table 2. The participants' experiences of previous fasting on Yom Kippur in relationship to Doctors and Rabbis' consultation.

\begin{tabular}{lll}
\hline Item & N & \% \\
\hline Have You traditionally fasted on Yom Kippur? & 28 & 90.3 \\
Yes, I traditionally fast & 3 & 9.7 \\
No, I traditionally do not fast & & \\
Did You consult your Doctor about not fasting on Yom Kippur? & 17 & 54.8 \\
Asked this year & 4 & 12.9 \\
Asked in past & 2 & 6.5 \\
Asked this year and in past & 8 & 25.8 \\
Never asked & & \\
What did your doctor answer? & 1 & 3.2 \\
You are allowed to fast & 13 & 41.9 \\
You are allowed not to fast & 9 & 29 \\
You can fast partially or eat by Shiurim (Minimum Quantities) & & \\
Did You ask your Rabi about fasting on Yom Kippur? & 15 & 48.4 \\
Asked this year & 4 & 12.9 \\
Asked in previous years & 1 & 3.2 \\
Asked this year and in past & 11 & 35.5 \\
Never asked & & \\
The Rabbi's answer: & 0 & 0 \\
You may fast & 9 & 29 \\
You should not fast & 5 & 19.3 \\
You can fast partially or eat by Shiurim (Minimum Quantities) & 6 & 12.9 \\
You should ask your doctor & & 51.6 \\
The Rabbis and Doctors answers & 4 & 3.2 \\
Was difficult for me to receive for me & 16 & \\
I received the answer, agreed and followed it & 1 & \\
The answer did not influence & & \\
\hline
\end{tabular}

Table 3. The participants' experiences this year regarding fasting on Yom Kippur.

\begin{tabular}{lll}
\hline Item & N & \% \\
\hline Did you fast in this Yom Kippur & 6 & 19.3 \\
Yes & 13 & 42 \\
No & 12 & 38.7 \\
By Shiurim (Minimum Quantities) & & \\
Did You successfully complete the fast & 6 & 19.3 \\
Yes & 2 & 6.5 \\
No & 10 & 32.3 \\
By Shiurim (Minimum Quantities) & 5 & 16.1 \\
Your activity during the Fast & 1 & 3.2 \\
Normal & & \\
I felt more weak & 9 & 29 \\
Your activity during the Fast by Shiurim & 3 & 9.7 \\
Normal & & \\
I felt weaker &
\end{tabular}

\section{Discussion}

Jewish law requires all females over the age of 12, and males over 13 to fast on the specified fast days, especially on Yom Kippur. At the same time, Jewish law teaches that the sanctity of life overrides all these fasts ${ }^{[2]}$. If a person would in any 
way be risking his health by fasting, not only should he not fast, he must in fact eat or drink ${ }^{[3]}$. The medical literature review revealed a few date about Jewish fast and no published guidelines for Jewish fast days in patients treated with chemotherapy.

Dietary habits are altered by anti cancer therapy. Typical dietary guidelines for patients receiving chemotherapy focus on maintaining nutritional balance and avoiding/preventing deficiencies, thereby maintaining low BMI and minimizing gastrointestinal side effects (i.e. decreased appetite, nausea, taste changes or bowel changes) ${ }^{[4]}$. It is not clear, however, how to relate to prolonged fasting patients receiving chemotherapy treatment. Many oncologists avoid recommending a fasting to their patients, many of whom are emaciated and/or weakened by previous therapy ${ }^{[5]}$.

In a case study of ten patients who fasted either before or after (or both) chemotherapy treatment, typical side effects (fatigue, weakness and gastrointestinal side effects) were reduced ${ }^{[6]}$.

Zeneldin et al studied the patterns of fasting among 102 Muslim cancer patients during the month of Ramadan. They found, that $36 \%$ and $24 \%$ were partial and complete fast during Ramadan, but only $46 \%$ of them discuss the issue with their oncologists. Patients who are females, those with PS 0 to 1, those whose disease is a nonmetastatic solid tumor, and those receiving non-IV chemotherapy in the outpatient facilities were more likely to be fasting than their corresponding counterparts $^{[7]}$.

In our study, despite the doctor's and rabbi's prohibiting fasting, and Jewish law exempting the fast on Yom Kippur, most patients who traditionally fasted on Yom Kippur continue to fast on Yom Kippur after chemotherapy was initiated.

The limitations of our study include a small population selection, the results are supported only by patients subjective experience and neither vital signs or laboratory assessment were performed during and after fast.

Diabetes has been associated with increased risk of a variety of cancers, including cancers of the pancreas, liver, kidney, colon and rectal cancer. Fasting on Yom Kippur is a significant challenge for diabetic patients and their physicians ${ }^{[8]}$. In his manuscript Grajower suggested that the overwhelming majority of patients with type 1 or type 2 diabetes can, from the perspective of blood glucose control, safely fast on Yom Kippur ${ }^{[1]}$. He also recommended physician-patient discussion to prevent the patient from relying only on personal judgment and potentially taking too much medication, with the resulting development of hypoglycemia.

\section{Conclusion}

In our Oncology Day Care unit, most patients who traditionally fasted on Yom Kippur asked their doctors and Rabbis for permission to fast. Despite doctors and rabbis recommendations to the contrary, most patients continue to fast. The 25-hour Yom Kippur fast is generally well tolerated. Every patient, receiving chemotherapy, who intends to fast should ask his physician about assurance that fasting is safe. The physician should pay special attention to diabetic patients especially on insulin treatment, or on sulfonylureas. Some, but not all these patients, should avoid fasting. Oncology nurses are one of the main providers for cancer patients receiving chemotherapy and may be the first to discuss a fasting on Yom Kippur.

\section{References}

[1] Grajower MM. Management of diabetes mellitus on Yom Kippur and other Jewish fast days. Endocr Pract. 2008; 14 (3): 305-11. PMid:18463037 http://dx.doi.org/10.4158/EP.14.3.305

[2] Gesundheit B. Medicine and Judaism--a patient is forbidden to endanger his life in order to fast on Yom Kippur. Harefuah. 2009; 148(9): 583-5, 659. PMid:20070045 
[3] Steinberg A. Encyclopedia of Jewish Medical Ethics. Rosner F, trans. Nanuet, NY: Feldheim Publishers. 2003: $482-489$.

[4] Raffaghello L, Lee C, Safdie FM, et al. Starvation-dependent differential stress resistance protects normal but not cancer cells against high-dose chemotherapy. Proc Natl Acad Sci U S A. 2008; 105: 8215-8220. PMid:18378900 http://dx.doi.org/10.1073/pnas.0708100105

[5] Nutrition and physical activity guidelines for cancer survivors. CA Cancer J Clin. 2012; 62(4): 275-6. PMid:22570061 http://dx.doi.org/10.3322/caac.21146

[6] Safdie FM, Dorff T, Quinn D, et al. Fasting and cancer treatment in humans: a case series report. Aging (Albany NY). 2009; 1: 988-1007.

[7] Zeeneldin AA, Taha FM. Fasting among Muslim cancer patients during the holy month of Ramadan. Ann Saudi Med. 2012; 32(3): 243-9. PMid:22588434

[8] Kaplan M, Eidelman A, Aboulafia Y. Diabetic patients in the Yom Kippur fast--who can fast and how to treat the fasting patients. Harefua, 2009; 148: 586-691, 659, 658. 